JSACE 4/21

Characterization of Ternary Batched Concrete Parking Lots on the Ground Containing Saw Dust Ash and Egg Shell

Powder

Received

Accepted after revision $2017 / 12 / 28$
2017/10/22

\section{Characterization of Ternary Batched Concrete Parking Lots on the Ground Containing Saw Dust Ash and Egg Shell Powder}

\author{
Alban Chidiebere Ogbonna*, Mikailu Abubakar
}

Department of Civil Engineering, Waziri Umaru Federal Polytechnic, Birnin Kebbi, PMB 1034 Birnin Kebbi GPO, Birnin Kebbi city, Kebbi State, Nigeria

*Corresponding author: alban.ogbonna@yahoo.com

$\Gamma$ crossef http://dx.doi.org/10.5755/j01.sace.21.4.19331

The quality of a concrete parking lots, floors or slabs is highly dependent on achieving a hard and durable surface that is flat, relatively free of cracks and at the proper grade and elevation. The properties are determined by the aggregate characteristics, cementitious materials and the mixture proportions. Concrete industry is one of the largest consumers of natural resources due to which sustainability of concrete industry is under threat. The environmental and economic concern is the biggest challenge concrete industry is facing. This study addressed, the issues of environmental and economic concern through the use of saw dust ash and egg shell powder mixture as partial replacement of cement in concrete. Hydraulic Cement was replaced by the mixture of Saw Dust Ash and egg shell powder at 5\%, 10\%, 15\%, 20\% and $25 \%$ by weight. The cylindrical concrete specimens were tested for compressive strength, flexural strength, splitting tensile strength, slump and density. The compressive strength of the specimens was evaluated at the $3^{\text {rd }}, 7^{\text {th }}, 14^{\text {th }}, 28^{\text {th }}$ and $56^{\text {th }}$ days of age. The flexural strength and the splitting tensile strengths were evaluated at $14^{\text {th }}$ and 28 days of age. The results obtained satisfied the minimum specifications of relevant standards and manuals. The study concluded that mixture of saw dust ash and egg shell powder is a suitable supplementary cementitious material and can satisfactorily replace hydraulic cement up to $20 \%$ by weight in the construction and maintenance of concrete parking lot placed on the ground.

Keywords: compressive strength, concrete parking lot, egg shell powder, flexural strength, saw dust ash, supplementary cementitious material.

\section{Introduction}

According to ACl 330R, (2008), ACl 330.1M-14, (2015) and ACl 360R-10, (2010), concrete parking lots range in size from small, such as at corner convenience stores, to medium, such as at multi-unit housing projects, to large, such as those for shopping centers and office or commercial developments. Most parking areas include driveways, some of which need to accommodate relatively heavy loads. Special consideration may be needed if access to dumpsters is to be included. Accordingly, concrete parking lots are constructed with a wide variety of construction equipment, ranging from hand tools and vibratory screeds to large highway paving equipment or laser screeds. Because of the relatively high stiffness of concrete pavements, loads are spread over larger areas of the subgrade compared with asphaltic pavements. As a result, thinner concrete pavements can be used for the same subgrade material. Additional benefits of using concrete 
to construct parking lots include the following: (a). Concrete surfaces resist deformation from maneuvering vehicles; (b). Concrete surfaces drain well with only minimal slopes; (c). Concrete has relatively simple maintenance requirements; (d). Traffic lane and parking stall markings can be incorporated into the jointing pattern; (e). Concrete is minimally affected by leaking petroleum products; (f). The light-reflective surface of concrete can be efficiently illuminated with minimal energy requirements; and $(\mathrm{g})$. Concrete parking lots reduce the impacts of the urban heat island effect relative to those of asphalt parking lots by producing lower surface temperatures, thus providing a cooler urban environment and reducing ozone production.

Parking lots have most loads imposed on interior slabs surrounded by other pavements, providing some edge support on all sides. Highway and street pavements carry heavy loads along and across free edges and are subjected to greater deflections and stresses. Street and pavements are usually designed to drain towards an edge where the water can be carried away from the pavement (ACl 330R, 2008, ACl 330.1M-14, 2015 and ACl 360R-10, 2010).

Concrete parking lots on the ground and Slabs-on-ground are defined as: slabs, supported by ground, whose main purpose is to support the applied loads by bearing on the ground. The slabs are of uniform or variable thickness and it may include stiffening elements such as ribs or beams. The slab may be unreinforced or reinforced with non prestressed reinforcement, fibers, or post tensioned tendons. The reinforcement may be provided to limit crack widths resulting from shrinkage and temperature restraint and the applied loads. Post-tensioning tendons may be provided to minimize cracking due to shrinkage and temperature restraint, resist the applied loads, and accommodate movements due to expansive soil volume changes ( $\mathrm{ACl} 330 \mathrm{R}, 2008, \mathrm{ACl}$ 330.1M-14, 2015 and ACl 360R-10, 2010). Fig. 1 (a and b) show typical example of concrete parking lots and slabs on ground.

In a study Mohammad et al (2015), concluded that saw dust ash is a suitable material for use as a pozzolan, since it satisfied the requirement for such a material by having a combined $\left(\mathrm{SiO}_{2}+\mathrm{Al}_{2} \mathrm{O}_{3}+\mathrm{Fe}_{2} \mathrm{O}_{3}\right)$ of more than $70 \%$ and that Concrete becomes more workable as the saw dust ash (SDA) percentage increases meaning that less water is required to make the mixes more workable. This means that SDA concrete has lower water demand. They opined that the compressive strength generally increases with curing period and decreases with increased amount of saw dust ash (SDA). They suggested that only $10 \%$ substitution can be allowed at maximum and $5 \%$ substitution is adequate to enjoy maximum benefit of strength gain. Cement -saw dust ash concrete vary with mix proportion in a similar way as those of normal cement concretes (with $0 \%$ SDA) and the compressive strengths of cement-saw dust ash concretes increased with leanness of mix up to some level of leanness after which the strength reduced. The 50-day strength values of cement-saw dust blended concrete, sandcrete, and soilcrete are respectively 82-99\%, 75-95\%, and $74-96 \%$ of those for $100 \%$ cement concrete (Ettu et al, 2013). Early strength development was observed to be about $50-60 \%$ of their 28 days strength. Saw dust ash concrete can attain the same

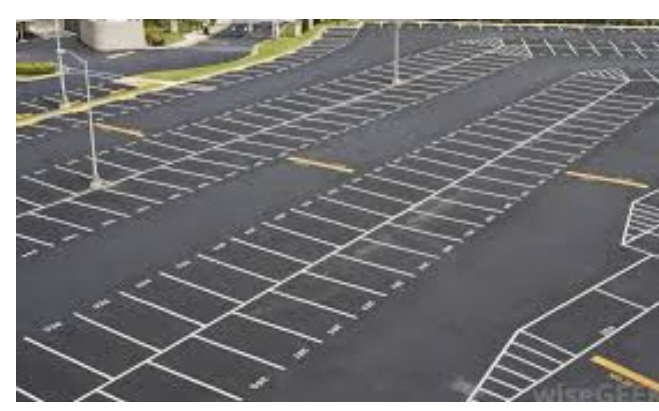

a

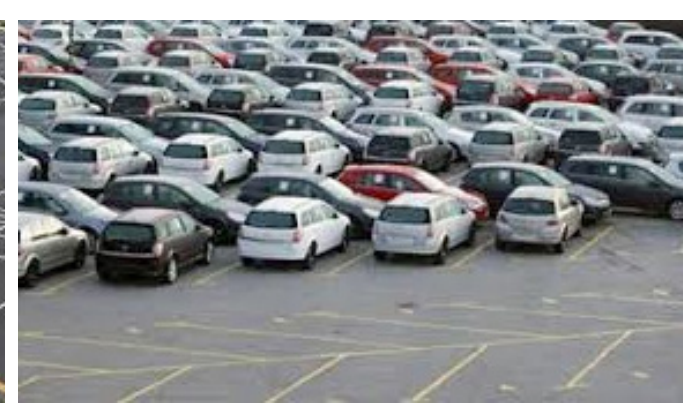

b
Fig. 1

Concrete parking lot on the ground $(a, b)$ 
order of strength as conventional concrete at longer curing periods. Saw dust ash can be used as partial replacement of cement up to a maximum of $10 \%$ by volume (Marthong, 2012). In a study Sanjay and Rahul (2016) concluded that 10\% replacement of saw dust ash gives $4.89 \%$ and $8.70 \%$ increase in the compressive strength of concrete at 7 days and 28 days.

Gowsika et al (2014) concluded that replacement of cement paste with 5\% Egg shell powder $+20 \%$ Microsilica gives no significant reduction in compressive strength properties and yields similar flexural strength when compared with that of conventional concrete. In a study, Anand et al (2017) concluded that the compressive strength of 20\% Eggshell powder Concrete increases up to 19.5\% than that of conventional concrete and the split tensile strength of $20 \%$ Eggshell powder Concrete increases to $5.16 \%$ than that of conventional concrete. The concrete compressive strength with egg shell powder as cement replacement material increases up to 15 percent without silica fume. Addition of silica fume also enhances the strength but in economical point of view only the egg shell powder replacement is sufficient enough for getting higher strength (Praveen, et al (2015).

Hydraulic cement is the most important and most expensive constituent of concrete, therefore the replacement of cement with certain percentage of these saw dust ash and egg shell powder to see their influence on slump, flexural strength and compressive strength at the same time reduces the cost of concrete and reduce the environmental hazard. These objectives justify the need for this research.

\section{Materials and methods}

\section{Cementitious materials}

The chemical analysis of the cementitious materials were carried out in line with the procedures specified in ASTM C114 - 15 (2015), ASTM D5370 - 14 (2014) and ASTM C311 / C311 M - 17 (2017).

\section{Aggregates}

The sand (fine aggregate) used for this study is locally available well graded river sand passing through sieve $4.75 \mathrm{~mm}$ but retained in sieve $2.36 \mathrm{~mm}, 1.18 \mathrm{~mm}, 600$ micron, 300 micron and 150 micron. Crushed granites passing through sieve $31.5 \mathrm{~mm}$ but retained in sieves $25 \mathrm{~mm}, 18.75 \mathrm{~mm}$, $16.0 \mathrm{~mm}, 12.5 \mathrm{~mm}, 9.5 \mathrm{~mm}, 6.25 \mathrm{~mm}$ and $4.75 \mathrm{~mm}$ was used as natural coarse aggregate (NCA). The natural coarse aggregate (NCA) and the fine aggregate were selected in accordance with the specifications of ASTM D 448 - 12 (2012), ACl 201.2R-16 (2016).ACl Education Bulletin E1-07 (2007), and ACl Education Bulletin E1-16 (2016).

\section{Concrete mix ratio}

The concrete specimens were batched at the mix ratio of 1:2: 3 by weight of cementitious materials, fine aggregate and coarse aggregate and marked as shown in Table 1. The concrete specimens were batched in line with the specifications of NEH-NRCS PART 642 (2009), ACI 330R (2009), ACl 330.1M-14 (2014), ACl 360R-10 (2010), and ACl 201.2R-16 (2016).

\begin{tabular}{|c|c|c|c|c|c|c|c|}
\hline \multirow{2}{*}{$\begin{array}{c}\text { Concrete } \\
\text { specimen } \\
\text { mark }\end{array}$} & \multirow{2}{*}{$\begin{array}{l}\text { Percentage } \\
\text { replacement of } \\
\text { cement with SDA } \\
\text { and ESP }(\%)\end{array}$} & \multirow{2}{*}{$\begin{array}{c}\text { Water-ce- } \\
\text { mentitious } \\
\text { materials } \\
\text { ratio }\end{array}$} & \multicolumn{3}{|c|}{ Cementitious materials $\left(\mathrm{Kg} / \mathrm{m}^{3}\right)$} & \multirow{2}{*}{$\begin{array}{c}\text { Fine } \\
\text { aggregate } \\
\left(\mathrm{Kg} / \mathrm{m}^{3}\right)\end{array}$} & \multirow{2}{*}{$\begin{array}{c}\text { Coarse } \\
\text { aggregate } \\
\left(\mathrm{Kg} / \mathrm{m}^{3}\right)\end{array}$} \\
\hline & & & Cement & $\begin{array}{l}\text { Saw dust } \\
\text { ash (SDA) }\end{array}$ & $\begin{array}{c}\text { Egg shell } \\
\text { powder (ESP) }\end{array}$ & & \\
\hline SD-ES1 & 0 & 0.55 & 400 & 0.00 & 0.00 & 800 & 1200 \\
\hline SD-ES2 & 10 & 0.55 & 360 & 20 & 20 & 800 & 1200 \\
\hline SD-ES3 & 20 & 0.55 & 320 & 40 & 40 & 800 & 1200 \\
\hline SD-ES4 & 30 & 0.55 & 280 & 60 & 60 & 800 & 1200 \\
\hline
\end{tabular}




\section{Aggregate properties}

Sieve analysis, specific gravity and water absorption were conducted for fine aggregate, and coarse aggregate in accordance with the specifications of ASTM D448 (2012), CADOT (2015), TXDOT (2015) and NYSDOT (2014). The aggregate impact value (AIV) test, aggregate crushing value (ACV) test and Los Angeles abrasion value test were conducted for the coarse aggregate in line with the specified procedures in ASTM D448 (2012), CADOT (2015), TXDOT (2015) and NYSDOT (2014).

\section{Concrete properties}

The slump value of all the fresh concrete mixtures were evaluated immediately after batching. The compressive strength value of the concrete were evaluated on the $3^{\text {rd }}, 7^{\text {th }}, 14^{\text {th }}, 28^{\text {th }}$, and $56^{\text {th }}$ days of age. The splitting tensile strength value was evaluated at the $14^{\text {th }}$ and $28^{\text {th }}$ day age. The specimens used for the compressive strength and splitting tensile strength tests were cylindrical in shape and measured $150 \mathrm{~mm}$ diameter and 300 long. The flexural strength value was evaluated at the $14^{\text {th }}$ and $28^{\text {th }}$ day age. The beam specimens used for the flexural strength test measured $150 \mathrm{~mm}$ width, $150 \mathrm{~mm}$ depth and $700 \mathrm{~mm}$ long. Depth to effective span ratio of 4 was maintained during the flexural test. The sump, compressive strength, splitting strength and flexural strength tests were carried out in line with the procedures specified in ACI 330R (2008), ACl 330.1M-14 (2015), ACI 360R-10 (2010), ACI 201.2R-16 (2016), CADOT (2015), TXDOT (2015) and NYSDOT (2014).

\section{Cementitious materials}

The hydraulic cement used in this study conform to the specifications of ASTM C150/ C15016 el (2016), ASTM C1157/C1157M-17 (2017) and AASHTO M85 (2016). The Egg shell powder was prepared in line with the specifications of $\mathrm{ACl} 232.1 \mathrm{R}-12$ (2012), and ASTM C618-15 (2015). The saw dust ash conform to the specification of ASTM C618 -15 (2015), ACl Education Bulletin E3-13 (2013), FHWA-HIF-16-001 (216), $\mathrm{ACl}$ Education Bulletin E3-13 (2013), ACl 232.2R-96 (2002) and ACl 232.1R-12 (2012) for Class $\mathrm{F}$ fly ash. According to FHWA-HIF-16-001 (2016) and ASTM C618-15 (2015), class F fly ash is defined as having a sum of the oxides $\left(\mathrm{SiO}_{2}, \mathrm{Al}_{2} \mathrm{O}_{3}+\mathrm{Fe}_{2} \mathrm{O}_{3}\right)$ equal or greater than $70 \%$ and Class $\mathrm{C}$ fly ash as having the sum

\begin{tabular}{c|c|c|c|c}
\hline $\mathrm{S} / \mathrm{N}$ & Oxides & Cement (\%) & ESP (\%) & SDA (\%) \\
\hline 1. & $\mathrm{SiO}_{2}$ & 21.8 & 0.08 & 65.79 \\
\hline 2. & $\mathrm{Al}_{2} \mathrm{O}_{3}$ & 6.6 & 0.03 & 4.88 \\
\hline 3. & $\mathrm{Fe}_{2} \mathrm{O}_{3}$ & 4.1 & 0.02 & 2.01 \\
\hline 4. & $\mathrm{CaO}$ & 60.1 & 52.1 & 9.39 \\
\hline 5. & $\mathrm{MgO}$ & 2.1 & 0.01 & 3.92 \\
\hline 6. & $\mathrm{Na}_{2} \mathrm{O}$ & 0.4 & 0.15 & 0.07 \\
\hline 7. & $\mathrm{~K}_{2} \mathrm{O}$ & 0.4 & - & 2.68 \\
\hline 8. & $\mathrm{SO}_{3}$ & 2.2 & 0.62 & 0.98 \\
\hline 9. & $\mathrm{LOI}$ & 2.3 & 42.2 & 4.56 \\
\hline 10. & Others & - & 4.79 & 5.72 \\
\hline
\end{tabular}

\section{Results and discussion} of the oxides $\left(\mathrm{SiO}_{2},+\mathrm{Al}_{2} \mathrm{O}_{3}+\mathrm{Fe}_{2} \mathrm{O}_{3}\right)$ equal or greater than $50 \%$. Table 2 shows the chemical composition of Saw Dust Ash (SDA), egg shell powder (ESP) and Cement.

\section{Aggregates characteristics}

The results of the gradation of coarse aggregate, and fine aggregate are shown in Table 3. The results of the physical and mechanical properties of the coarse aggregate, and fine aggregate are shown in Table 4. The fine and coarse aggregate properties conform to specifications of ASTM D448 (2012), CADOT (2015), TXDOT (2015), NYSDOT (2014), ACl 201.2R-16 (2016), ACl Education Bulletin E1-07 (2007), and ACI Education Bulletin E1-16 (2016). 


\section{Table 3}

Sieve analysis results of coarse and fine aggregate

\section{Table 4 \\ Physical and mechanical properties of the aggregate used}

\begin{tabular}{|c|c|c|c|c|c|c|}
\hline \multirow{2}{*}{$\begin{array}{l}\text { Sieve } \\
\text { size } \\
(\mathrm{mm})\end{array}$} & \multicolumn{3}{|c|}{ Coarse aggregate (initial weight $=1000 \mathrm{~g}$ ) } & \multicolumn{3}{|c|}{ Fine aggregate (initial weight $=1000 \mathrm{~g}$ ) } \\
\hline & $\begin{array}{l}\text { Percentage } \\
\text { retained } \\
(\%)\end{array}$ & $\begin{array}{l}\text { Cumulative } \\
\text { percentage } \\
\text { retained (\%) }\end{array}$ & $\begin{array}{c}\text { Percentage } \\
\text { passing/finer } \\
(\%)\end{array}$ & $\begin{array}{l}\text { Percentage } \\
\text { retained } \\
(\%)\end{array}$ & $\begin{array}{l}\text { Cumulative } \\
\text { percentage } \\
\text { retained (\%) }\end{array}$ & $\begin{array}{l}\text { Percentage } \\
\text { passing/ } \\
\text { finer }(\%)\end{array}$ \\
\hline 31.5 & 0.00 & 0.00 & 100 & - & - & - \\
\hline 25.0 & 1.3 & 1.3 & 1.3 & - & - & - \\
\hline 19.0 & 12.4 & 13.7 & 86.3 & - & - & - \\
\hline 16.0 & 21.84 & 35.54 & 64.46 & - & - & - \\
\hline 12.5 & 28.78 & 64.32 & 35.68 & - & - & - \\
\hline 9.5 & 22.65 & 86.97 & 13.03 & - & - & - \\
\hline 6.5 & 9.8 & 96.77 & 3.23 & & & \\
\hline 4.75 & 2.63 & 99.40 & 0.6 & 0.00 & 0.00 & 100 \\
\hline 2.36 & - & - & - & 14.22 & 14.22 & 85.78 \\
\hline 1.18 & - & - & - & 19.07 & 33.29 & 66.71 \\
\hline 0.6 & - & - & - & 23.45 & 56.74 & 43.26 \\
\hline 0.3 & - & - & - & 21.06 & 77.80 & 22.20 \\
\hline 0.15 & - & - & - & 17.11 & 94.91 & 5.09 \\
\hline 0.075 & - & - & - & 3.64 & 98.55 & 1.45 \\
\hline Total (\%) & 99.4 & 398 & - & 98.55 & 375.51 & \\
\hline
\end{tabular}

\begin{tabular}{l|c|c|c|c|c}
\hline \multicolumn{1}{|c|}{ Aggregate } & $\begin{array}{c}\text { Specific } \\
\text { gravity }\end{array}$ & $\begin{array}{c}\text { Water ab- } \\
\text { sorption (\%) }\end{array}$ & $\begin{array}{c}\text { Aggregate crush- } \\
\text { ing value (\%) }\end{array}$ & $\begin{array}{c}\text { Aggregate im- } \\
\text { pact value (\%) }\end{array}$ & $\begin{array}{c}\text { Los Angeles abra- } \\
\text { sion value (\%) }\end{array}$ \\
\hline Fine & 2.633 & 1.434 & - & - & - \\
\hline $\begin{array}{l}\text { Natural Coarse } \\
\text { (crushed granite) }\end{array}$ & 2.731 & 1.23 & 19.63 & 22.54 & 24.71 \\
\hline
\end{tabular}

\section{Concrete properties}

Table 5, shows the slump, densities, and compressive strength values of concrete at different percentage replacement of cement with a mixture of saw dust ash and egg shell powder. The densities and slump values increase with increase in percentage replacement of cement. There is no significant change in compressive strength values of concrete containing $0 \%$ to $20 \%$ replacement of cement with a mixture of saw dust ash and egg shell powder as shown in Table 5 and Fig. 2. Concrete specimens containing Saw dust ash and egg shell powder mixture show increase in splitting tensile strength and flexural strength values as shown in Fig. 3 and 4 . The compressive strength results of $0 \%$ to $20 \%$ replacement of cement with a mixture of saw dust ash and egg shell powder satisfied the minimum 28 days strength of $31 \mathrm{~N} / \mathrm{mm}^{2}$ to $41 \mathrm{~N} / \mathrm{mm}^{2}$ and $35 \mathrm{~N} / \mathrm{mm}^{2}$ to $41 \mathrm{~N} / \mathrm{mm}^{2}$ specified in ACl 330R (2008), ACl 330.1M-14 (2015), ACl 360R-10 (2010), ACl 201.2R16 (2016), CADOT (2015), TXDOT (2015) and NYSDOT (2014) for standard and high performance Concrete Parking Lots on the Ground. The maximum compressive strength and density values occurred at $10 \%$ replacement of cement with SDA and ESP. 


\begin{tabular}{|c|c|c|c|c|c|c|c|c|}
\hline $\begin{array}{l}\text { Cube } \\
\text { mark }\end{array}$ & $\begin{array}{c}\text { Percentage replacement of } \\
\text { cement with SDA and ESP (\%) }\end{array}$ & $\begin{array}{l}\text { Slump } \\
(\mathrm{mm})\end{array}$ & $\begin{array}{l}\text { Density } \\
\mathrm{Kg} / \mathrm{m}^{3}\end{array}$ & $\begin{array}{c}3^{\text {rd }} \text { day N/ } \\
\mathrm{mm}^{2}\end{array}$ & $\begin{array}{l}7^{\text {th }} \text { day } \\
\mathrm{N} / \mathrm{mm}^{2}\end{array}$ & $\begin{array}{l}14^{\text {th }} \text { day } \\
\mathrm{N} / \mathrm{mm}^{2}\end{array}$ & $\begin{array}{l}28^{\text {th }} \text { day } \\
\mathrm{N} / \mathrm{mm}^{2}\end{array}$ & $\begin{array}{c}56^{\text {th }} \mathrm{N} / \\
\mathrm{mm}^{2}\end{array}$ \\
\hline SD-ES1 & 0 & 93 & 2432 & 17.10 & 25.20 & 30.58 & 37.21 & 44.81 \\
\hline SD-ES2 & 10 & 111 & 2441 & 21.20 & 27.60 & 33.08 & 40.02 & 45.61 \\
\hline SD-ES3 & 20 & 109 & 2440 & 17.08 & 24.50 & 29.30 & 36.08 & 42.32 \\
\hline SE-ES4 & 30 & 121 & 2437 & 13.40 & 19.80 & 24.60 & 30.37 & 36.86 \\
\hline
\end{tabular}

\section{Table 5}

Average

Compressive

Strength Test

Results $\left(f_{c k}\right)$
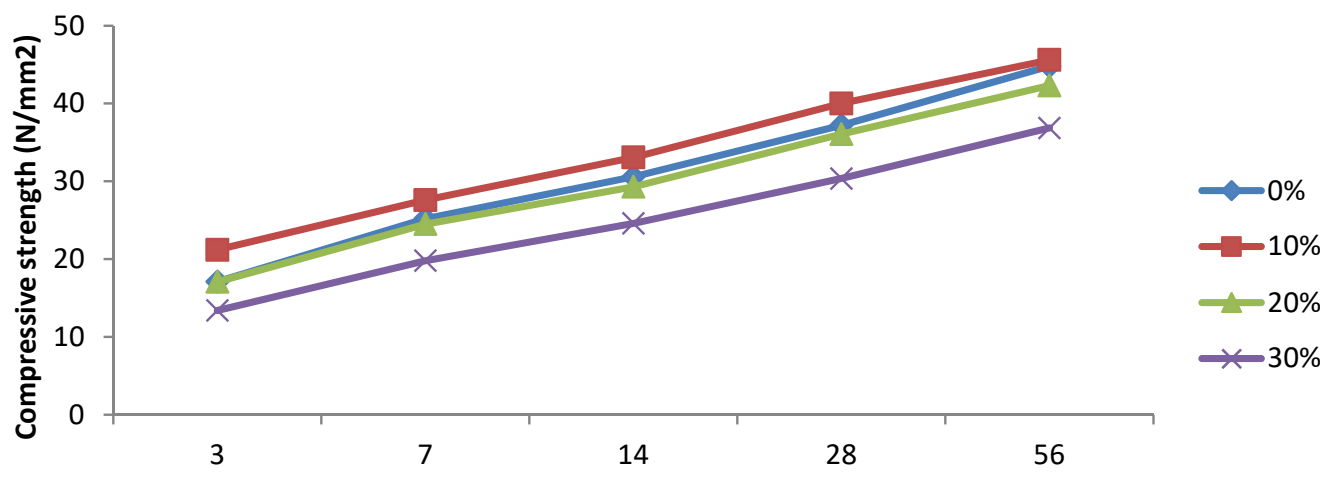

$-20 \%$

$\times 30 \%$

Curing Age (days)

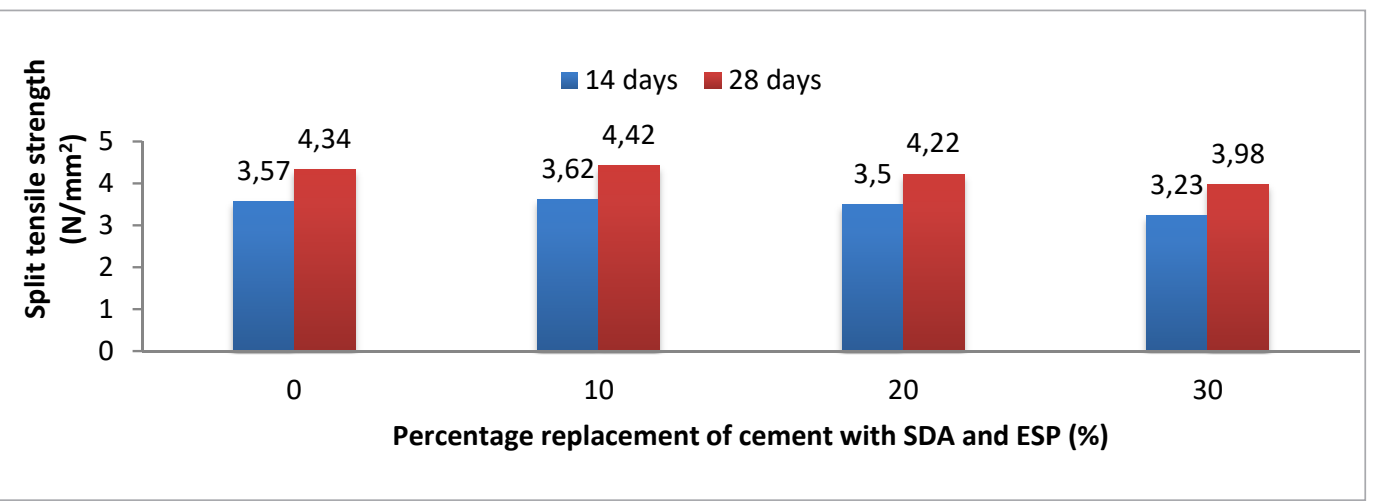

Fig. 3

Relationship of the $14^{\text {th }}$ and $28^{\text {th }}$ days splitting tensile strength with percentage replacement of cement with SDA and ESP

\section{Fig. 4}

Relationship of the $14^{\text {th }}$ and $28^{\text {th }}$ days flexural with percentage replacement of cement with SDA and ESP 


\section{Conclusions}

The following conclusions were drawn at the end of this study.

1 A mixture of saw dust ash and egg shell powder gives good pozzolan and cementitious material and can used in ternary batched concrete parking lots on the ground.

2 The concrete batching and mixing proportion of 1: 2:3 of cementitious materials, fine aggregate and coarse aggregate gives cementitious content of $400 \mathrm{~kg} / \mathrm{m}^{3}$ and fine to total aggregate of 0.4 . This satisfied the minimum cementitious content of $300 \mathrm{~kg} / \mathrm{m}^{3}$ to $360 \mathrm{~kg} / \mathrm{m}^{3}$ and fine to total aggregate ratio of 0.35 to 0.45 specified in ACI 330R (2008), ACl 330.1M-14 (2015), ACl 360R-10 (2010), ACl 201.2R-16 (2016), CADOT (2015), TXDOT (2015) and NYSDOT (2014).

3 Using a mixing ratio and proportion specified by relevant standards, concrete mixtures 3 containing up to $20 \%$ saw dust ash and egg shell powder exhibit similar characteristics compared to non-saw dust ash and egg shell concrete.

The use of saw dust ash and egg shell powder as supplementary cementitious material in 4 preparing ternary concrete mixtures in construction and maintenance of concrete parking lots on the ground should be encouraged. This leads to cost effective and environmental friendly construction. It also leads savings in the quantity of cement that would have been consumed and as such sustainability of the cement industry can be guaranteed.

5 Concrete containing a mixture of saw dust ash and egg shell powder should be well compact$\zeta$ ed to give densities above $2400 \mathrm{~kg} / \mathrm{m}^{3}$ and above. Above all the concrete must be prepared with well graded fine and coarse aggregate to give acceptable compressive strength values.

\section{References}

AASHTO M85-16, Standard specification for Portland cement. American Association of State Highway and Transportation Officials, Washington, DC, USA. 2016; http://www.transportation.org/M85-16.

ACl 330R. Guide for the design and construction of concrete parking lots. American concrete institute. 2008; http://www.concrete.org/330R

$\mathrm{ACl}$ 330.1M-14. Specification for Unreinforced Concrete Parking Lots and Site Paving. American concrete institute. 2015; http://www.concrete. org/330.1m-14 ISBN: 978-1 - 94272-707-1

ACl 360R-10. Guide to design of slabs-on-ground. American concrete institute. 2010; http://www.concrete.org/360R-10 ISBN: 978-0-87031-371-4

ACl 201.2R-16. Guide to Durable Concrete. American concrete institute. 2016; http://www.concrete. org/201.2R-16 ISBN: 978-1-945487-39-2

$\mathrm{ACl}$ 232.1R-12. Report on the Use of Raw or Processed Natural Pozzolans in Concrete. American concrete institute. 2012; http://www.concrete. org/232.1R-12

ACl 211.4R-08. Guide for Selecting Proportions for High Strength Concrete Using Portland cement and other Cementitious Material. American concrete institute. 2008; http://www.concrete.org/211.4R. ISBN: 9780870313141

$\mathrm{ACl}$ 232.2R-96. Use of Fly Ash in Concrete. American concrete institute. 2002; http://www.concrete. org/232.2R-96 ISBN: 978-0-87031-371-4
ACl 304.4R-00. Guide for Measuring, Mixing, Transporting, and Placing Concrete. American concrete institute. 2000; http://www.concrete.org/304.4R-00.

ACl Education Bulletin E3-13. Cementitious Materials for Concrete. American concrete institute. 2013; http://www.concrete.org/Education bulletin/E3-13.

ACl Education Bulletin E1-07. Aggregates for Concrete. American concrete institute. 2007; http:// www.concrete.org/Education bulletin/E1-07.

ACl Education Bulletin E1-16. Aggregates for Concrete. American concrete institute. 2016; http://www. concrete.org/Education bulletin/E1-16v3. ISBN: 978942727-75-0.

Anand B.A, Ramprasanth A.A, and Shanmugavadivu V.A. Experimental Investigation on Partial Replacement of Egg Shell Powder in Conventional Concrete. International Journal of Cem Tech Research, 2017; Vol. 10 (8), Pp. 453-457.

ASTM C150/150M-16e1, Standard specification for Portland cement. ASTM International, West Conshohocken PA. 2016; http:// www.astm.org/C150

ASTM C618-15. Standard Specification for Coal Fly Ash and Raw or Calcined Natural Pozzolan for use in Concrete. ASTM International, West Conshohocken PA. 2015; http:// www.astm.org/C618

ASTM C114 - 15. Standard Test Methods for Chemical Analysis of Hydraulic Cement. ASTM international, West Conshohocken, PA, 2015; https://www. astm.org/C114-15 
ASTM D5370 - 14. Standard Specification for Pozzolanic Blended Materials in Construction Applications. ASTM international, West Conshohocken, PA, 2014; https://www.astm.org/D5370-14

ASTM D448-12 (2012). Standard classification for sizes of aggregates for roads and bridge construction. ASTM international, West Conshohocken, PA, 2012; https://www.astm.org/D448.

CADOT. Standard Specifications, Department of Transportation, California State Transportation Agency, State of California, USA, 2015; https:// www.dot.ca.gov/hq/standards.

Ettu, L. O, Njoku, F. C, Anya, U. C, Amanze, A. P. C, and Arimanwa, M. C. Variation of OPC-Saw Dust Ash Composites Strength with Mix Proportion. International Journal of Advancements in Research \& Technology, 2013; Volume 2 (8).

Gowsika D, Sarankokila S, and Sargunan (2014). Experimental Investigation of Egg shell powder as Partial Replacement with Cement in Concrete, 2014; Vol. 1492), Pp. 65-68.

Marthong, C. "Sawdust Ash (SDA) as Partial Replacement of Cement," International Journal of Engineering Research and Applications (IJERA), 2012; Vol. 2 (4), Pp. 1980-1985.

Mohammad, I. M., Syed, R. J., Junaid, A. P., Syed, A. N., and Khubbab, F. M. Partial Replacement of Cement by Saw Dust in Concrete: A sustainable Approach.
International Journal of Engineering Research and Development, 2015; Vol 11 (2), Pp. 44-53.

Mohamed, A.M, Dinesh K.M, Milan C.J and Vani, G. Replacement of Cement Using Egg Shell Powder. SSRG International Journal of Civil Engineering, 2016; Vol. 3(3), Pp. 1-2. https://doi. org/10.14445/23488352/IJCE-V313P101

NEH-NRCS PART 642. Specifications for Construction Contracts. National Resources Conservation Service, National Engineering Handbook. US Department of Agriculture, Independence Avenue, Washington, D. C, USA. 2009; https://www.nrsc.usda.gov/part642

NYSDOT. Standard Specifications. New York State Department of Transportation, State of New York, 2014; https://www.dot.ny.gov/standards

Praveen, K.R, Vijaya, S.R, and Jose, R.B. Experimental Study on Partial Replacement of Cement with Egg Shell Powder. International Journal of Innovations in Engineering Technology, 2015; Vol. 5(2), Pp. 334-341.

Sanjay Chugh and Rahul Bansal. Study on saw dust as partial replacement with cement. International Journal of Engineering Technology, Science and Research. 2016; Vol. 3(4) Pp. 126-130.

TXDOT. Standard Specifications for Construction and Maintenance of Highway, Street, and Bridges. Texas Department of Transportation, State of Texas, USA, 2014; https://www.ftp.dot.state.tx.us/standards.

\section{ALBAN CHIDIEBERE OGBONNA}

\section{Lecturer/Researcher}

Department of civil engineering, college of engineering, Waziri Umaru Federal Polytechnic, Birnin Kebbi, Kebbi State, Nigeria

\section{Main research area}

Pavement material engineering, Traffic engineering and Transportation engineering

\section{Address:}

Department of civil engineering, college of engineering, Waziri Umaru Federal Polytechnic, Birnin Kebbi, P.M.B 1034, Birnin Kebbi GPO, Birnin Kebbi City, Kebbi State, Nigeria

Tel. +2348039256430

E-mail: alban.ogbonna@yahoo.com

\section{ABUBAKAR MIKAILU \\ Lecturer/Researcher authors}

About the

Department of civil engineering, college of engineering, Waziri Umaru Federal Polytechnic, Birnin Kebbi, Kebbi State, Nigeria

\section{Main research area}

Structural engineering, Foundation engineering and concrete technology

\section{Address:}

Department of civil engineering, college of engineering, Waziri Umaru Federal Polytechnic, Birnin Kebbi, P.M.B 1034, Birnin Kebbi GPO, Birnin Kebbi City, Kebbi State, Nigeria Tel. +2347031276736

E-mail: mikaabuba@gmail.com 